\title{
THE ROLE PERCEPTION OF FEMALE SECONDARY SCHOOL ADMINISTRATORS IN EKITI STATE
}

\author{
Olaleye Florence Oluremi Ph.d* \\ *Faculty of education department of educational management ekiti state university, ado-ekiti
}

*Corresponding Author: -

Email:-funsolaleye@yahoo.com

\begin{abstract}
: -
This study examined the self-perceived role of female administrators of secondary schools in Ekiti State, Nigeria. Such perception is based on performing specific tasks, and is compared to the role of female administrators as perceived by the teachers under them and the board members of the Teaching Service Commission. A purposive sampling technique was used to select thirty (30) female principals/administrators, 670 teachers under them and five Board members. A 40 item questionnaire, arranged in a summated rating Likert Whitney U-test was employed to test the significance difference between the self-perceived role of female administrators and their role as perceived by both the teachers and Board member. Findings showed that self-perceived role of the female secondary school administrators is significantly different from her role as perceived by the teachers under them in

(1) Staff Development

(2) Instructional Supervision and

(3) Finance and Budgeting
\end{abstract}

Whereas both the female administrators and their superordinates (Board members) perceived the role of the female administrators in the following order of importance.

1. Staff development

2. Finance and Budgeting

3. Community Relations

4. Instructional Supervision

5. Student welfare Services

It was recommended that both male and female school administrators need some orientation courses on professional matters regularly.

Keywords: Female administrators, Roles, perceived, Teachers, Board members.

\section{(ㄷ) (3) (1)}




\section{INTRODUCTION}

The school administrator or the principal is the person responsible for coordinating the activities of the schools using the resources at his or her disposal in such a way that the schools objectives are achieved. He or she is essentially an organiser and implementer of plans, policies and programmes meant for specific educational objectives.

In all secondary schools, the principals are regarded as school administrators. It is therefore expected that he or she will perform a variety of tasks or operational areas of administration. These tasks are school community relationship, curriculum instruction, student welfare service, staff personnel management. Finance and Budgeting (Nwankwo 1982) and (Peretomode 1991) noted. In the discharge of these responsibilities the school administrator is expected to plan, control, organise, coordinate and direct human and non-human resources in the organisation. These functions are highlighted by Adeleke (2001) and Onifade 2004).

In the context of the effective management of schools there is some evidence to suggest that the role of the principal is shaped by a number of non-school factors such as personal characteristics, sex, experiences and training. Research has failed to bear out this common-sense notion. Olaleye (2001) for example found no relationship between effective principalship and sex. It is further acquired that most of the personality traits like dependability and emotional stamina that have been found to be associated with administration are skills and competencies which could be acquired through experience and training. There is general agreement that it is easier to identify a leader that it is to articulate the exact and precise behaviour characteristics of leadership when considering leadership in the secondary schools as embodied in the principal it becomes apparent that the very effectiveness of education may well depend upon the degree to which the role of the school administrator are fully understood by the subordinates, the super and the principal themselves.

Effectiveness in administration can be the congruence between expected administrative behaviour of an executive in relations to his or her administrative tasks (Balogun 1980). Effectiveness is determined by productivity, stability moral turnover rate, degree of integration, maximisation of individual potentialities and values contributed to the society.

A school with low productivity, low morale, high turnover of teachers, disgruntled teachers with little or no contribution to the society can be regarded as being ineffective. The individual who occupied a social position behaves in terms of her perception of the appropriate behaviour of that role. Role behaviour is a dynamic phenomenon. The actor's perception of her role may change as she interacts with others in the social system. The norms and expectations held by others may change over time.

Furthermore, the behaviour of different persons in the same role may change or vary. As such administrator identifies herself as the leader in a particular school systems. She defines certain types of behaviour, she understands appropriate for her in that role. Some of the identified tasks expected of a principal include school finance and budgeting staff personnel management, supervision of instructional programmes and community relationship.

Perhaps, at no other time in the history of the secondary school education in Nigeria has the principal been faced with the multitude of challenges that come his or her way today. Challenges such as youth unrest, examination malpractices, cultism, low level of academic performance, drug, and attempts of parents, teachers and the State Schools, Management Board to restore the lost image of the secondary school (Okebukola 1996). What is the lost image of school? It is the quality of teaching, Quality of learning, usefulness of school programme for the hope of the society that can depend upon the secondary school graduates as a tool per excellence for building.

A free and democratic society

A just and eqalitarian society.

A united strong and self-reliant Nation

A land of bright and full opportunities for all citizens.

Laudable as this policy is, the system needs a pragmatic, visionary school administrator who can manage human and financial resources in an efficient manner to enable the realisation of the aim of secondary school education in Nigeria. Women in the upper echelons of educational Administration/principal find themselves in situation similar to those of women managers and executives in the corporate world. Both of women managers operate in male dominated fields where descriptions of appropriate leadership behaviour have been based on male models. (Burke \& Nelson 2002). Research findings on task behaviour of a principal seems to be determined more by the nature of the principalship than by the sex of the principal (Olaleye 2005). Assumptions which have been made about administration being a "mans" job has no validity. The overall task performance behaviour of the male and female principals was found to be similar. Thus female administrators of secondary schools are used as a case study in this paper.

\section{Objectives of the Study}

The research objective was to determine the self-perceived role of the female secondary school administrators in specific tasks such perception was compared to the role of the female administrators as perceived by both the teachers under them and the Board members of the state schools management board.

\section{Hypotheses}

1. There is no significant difference between the self perceived role of the female secondary School administrators and her role as perceived by the teachers.

2. There is no significant difference between the self perceived role of the female secondary school administrators and their role as perceived by the Board members of the State. School management Board. 


\section{Research Methodology}

Descriptive research of the survey design was adopted in this study.

\section{Population}

The population of the study consisted of 30 female school administrators purposively selected from 186 secondary schools administrators in the state 670 teachers under them and the five board members of the State. Teaching Service commission were also purposively selected.

\section{Research Instrument}

A 40- item questionnaire, arranged in a summated rating likert-type scale was used for the study. In order to determine the degree of belongingness of the tasks to the principal of a secondary school, each respondent was asked to respond with a degree of agreement or disagreement by circling one of the members. O zero to 7 (Seven). 7 represented the fact that a certain task is very much the principal's task, while 0 (zero) indicated that the task is not the principals task at all. Thus, each respondent was placed somewhere on the agreement continuum of the rating scale. Questions measuring the role perception were asked under these variables.

1. Providing leadership in the supervision of instructional programme.

2. Maintenance of staff welfare and development.

3. Monitoring school finance and budget

4. Maintaining Student Welfare Services.

5. Sustaining school community relations.

The instrument for the study were subjected to screening by specialists in the area of tests and measurement. The judgement of experts were used to determine the content.

\section{Validity of the items}

The reliability of the instrument was ensured using test- retest method. The instrument was administered to the purposive sample of 705 respondents. 30 female school administrators/principals. 670 teachers under them, and all the five Board Members. All of responded giving a return rate of $100 \%$.

\section{Data Analysis}

The data collected for the study were analysed using both descriptive and Mann Whitney U-test as a non parametric statistical test using the variance of the two groups (teachers and administrators) were different. The same type of test was also used to determine the level of significance of the self- perceived role of the female administrators and her role as perceived by the Board members. Analyses were done for each of the two hypotheses and in each case, each of the five variables was involved. A summary of the responses of the principals and those of the teachers under them is given on table 1 below.

Table 1: There is no significant relationship between the self-perceived role of the female secondary school administrators and her role as perceived by the teachers.

\begin{tabular}{|l|l|l|l|l|l|}
\hline Variables & Items & $\bar{X}$ & SD & $\bar{X}$ & SD \\
\hline Community Relations & 8 & 5.71 & 1.04 & 5.19 & 1.49 \\
\hline Staff Development & 6 & 6.49 & 0.61 & 5.61 & 1.55 \\
\hline Finance and Budgeting & 8 & 6.27 & 0.66 & 5.51 & 1.57 \\
\hline Instructional Supervision & 12 & 5.69 & 0.79 & 4.60 & 1.32 \\
\hline Student welfare & 6 & 4.18 & 1.62 & 3.41 & 1.43 \\
\hline
\end{tabular}




\section{Result of hypothesis One}

In the null form of the first hypothesis, it was held that there is no significant difference between self-perceived role of female secondary school administrator and her role as perceived by the teachers under her. The results of the analysis of the relevant data are given below

Table II- Results for hypothesis I

\begin{tabular}{|l|l|l|l|}
\hline Variables & U-Value & Computed Z-Value & Given Probability \\
\hline Community Relations & 497.5 & 1.205 & .1131 \\
\hline Staff Development & 628.0 & 3.237 & .0007 \\
\hline Finance Budgeting & 583.0 & 2.536 & .0055 \\
\hline Instructional Supervision & 659.0 & 3.718 & .0001 \\
\hline Student Welfare & 510.5 & 1.408 & .0792 \\
\hline
\end{tabular}

As shown in Table II, the Mann Whitney u-test yielded a z - relations and a $\mathrm{z}$-value of 1,205 for community relations and $\mathrm{az}-$ value of 1,408 for student welfare. In this case these two variables the given probability is greater than 0.05 , therefore $\mathrm{HQ}_{1}$ was rejected in respect of the remaining three variables of staff development, instructional programme supervision and finance and Budgeting. This is because in each case the $\mathrm{Z}$-value has a probability that is less than 0.05 .

\section{Result of Hypothesis two}

In the null form, the second hypothesis held that there is no significant difference between the self perceived role of the female secondary school administrators and their role as perceived by the Board Members who enact the role. The result of the $\mathrm{u}$-test for hypothesis 2 are given in table III below.

Table III: School Administrators Responses and Board members Responses

\begin{tabular}{|l|lr|l|l|l|}
\hline Variables & \multicolumn{2}{|c|}{$X$} & S.D & Z-value & Probability \\
\hline Community Relation & a. & 5.71 & 1.01 & 1.06 & .145 \\
& b. & 5.81 & 0.85 & & \\
\hline Staff Development & a. & 6.49 & 0.61 & 1.13 & .129 \\
& b. & 6.09 & 0.62 & & \\
\hline Finance \& Budgeting & a. & 6.27 & 0.66 & 0.06 & .477 \\
& b. & 6.30 & 0.56 & & \\
\hline Instructional & a. 5.69 & & 0.79 & 0.50 & .066 \\
Supervision & b.5.67 & & 0.80 & & \\
\hline Student welfare & a. 4.18 & & 1.62 & 0.63 & .264 \\
& b. 4.27 & 0.48 & & \\
\hline
\end{tabular}

a. In this table, refers to the mean and standard deviation of the female administrators while (b) refers to the mean and standard deviation of the Board Members. As shown on table III above, all the associated probability under HQ for all the five variables are higher than .05 . Therefore, HQ was retained in each of the five variables. Thus, based on the result of the analysis shown on Table III above, there was no significant difference between the self-perceived role of the female administrators and their role as perceived by the Board members. 
Table IV: Distribution of the responses of both female Administrators and the Board members.

\begin{tabular}{|c|c|c|c|c|}
\hline \multirow{3}{*}{\begin{tabular}{|l} 
Variables \\
Community Relation
\end{tabular}} & \multicolumn{3}{|c|}{ Percentage of Responses } & \\
\hline & \multicolumn{2}{|c|}{ Negative } & \multirow{3}{*}{$\begin{array}{l}\text { undecided } \\
2 \\
5\end{array}$} & \multirow{3}{*}{$\begin{array}{l}\text { Positive } \\
88 \\
85\end{array}$} \\
\hline & & 10 & & \\
\hline & & 10 & & \\
\hline \multirow[t]{2}{*}{ Staff Development } & \multicolumn{2}{|c|}{ a.3 } & $\beta$ & 94 \\
\hline & \multicolumn{2}{|c|}{ b. 7} & $\beta$ & 90 \\
\hline \multirow[t]{2}{*}{ Finance \& Budgeting } & \multicolumn{2}{|l|}{ a. 6} & 7 & 87 \\
\hline & \multicolumn{2}{|c|}{ b. 8} & 0 & 92 \\
\hline Instructional & a. & 12 & 8 & 80 \\
\hline Supervision & b. & 5 & 10 & 85 \\
\hline \multirow[t]{2}{*}{ Student welfare } & a. & 34 & 15 & 51 \\
\hline & b. & 23 & 20 & 57 \\
\hline
\end{tabular}

(a) Refers to the female administrators' responses while (b) refers to the responses of the Board members.

The analysis of available data shows that the distributions of responses are similar for the Board members and the female secondary school administrators. As shown on Table IV above, the responses from 0 to 3 are regarded as negative perception while 5 to 7 are for positive perception and 4 indicates indecision. The negative responses indicate that a given task is not the principal's task at all, while the positive responses indicate that given task is the principals. The highest cases of indecision from both the administrators and the Board Members are under the variable of student welfare,

On the average both the Board members and the Principals perceived the role of the female secondary school administrator in the following order.
(a) Staff Development
(b) Finance and budgeting
(c) Community Relations
(d) Instructional supervision
(e) Student Welfare

\section{Discussion}

In this study, it was shown that the tasks associated with community relations belong more to the female principal than those tasks associated with student welfare. But schools are built in the community by the Community for the education of its youth. These students are the most valuable item that these parents have in the school. Hence the teachers rated this item very important.

The findings also showed that there is a significant difference between the role perception of female administrators and their role as perceived by the teacher under them with respect to the variables of:

1. Staff development

2. Finance and budgeting

3. Instructional supervision

The differences are to be expected between the teachers and the principals. The differences in perception may be due to the fact these variables tend to touch the person of the teacher or the principal indirectly. 
It was hypothesised that there is significant difference between self-perceived role of female administrators and their role as perceived by the Board Members. In this study both the principals and the Board Members perceived the administrators role in the following order of belongingness of the tasks to the principal/ school administrators.

(1) Staff Development

(2) Finance and budgeting

(3) Community Relations

(4) Instructional Supervision

(5) Student Welfare

Both the principals and the Board members were aware of these tasks before. The board members set the policies and evaluate the principals. Thus, it is not surprising that both perceived the administrator role in the same order of belongingness of the tasks to the principal. The greatest difference in perception in this study was in the area of the administrator as the instructional leader. Most teachers in this study, relegated supervision of instructional programme to the fourth out of five positions. This may partly due to poor remuneration of teachers and irregular payment of salary for teachers.

Education stakeholders blamed teachers, and school administrators on poor academic performance of students. However, for good quality education, supervision of instructional programmes in the school should be of priority in the school system and also for school administrators.

\section{Conclusion and Recommendations}

In this study, it was discovered that the self-perceived role of the female secondary school administrator is significantly different from her role as perceived by the teacher under her in staff development, instructional Programme Supervision Finance and Budgeting. A second finding was that self-perceived role of female secondary school administrators and their role as perceived by the Board members are significantly similar.

Based on the findings, the following recommendations are made:

School administrators should bring the school closer to the community. She needs to be good in public relations and make the Parents Teacher Association and Governing Board of School functional Teachers should be encouraged to develop and perform better to attend seminars and Workshops. Principals of secondary schools should be acquainted with required managerial functions in order to perform their administrative duties and functions effectively and efficiently.

Government in conjunction with the school principal should place premium on teachers' welfare through efficient and effective remuneration of in-service training, reward for hardwork, and diligence in services and improved working conditions.

\section{REFERENCES}

[1].Adeleke A. (2001). Management Concepts and Applications, Lagos Concept publication limited.

[2].Balogun M.J. (1980). 'Managerial efficiency in the public sector: Patterns and problems in Nigeria, Ile-Ife University of Ife, Burke \& Nelson

[3].Burke, R., \& Nelson, D. (2002). Advancing women in Management: Progress and prospects,

[4].In R. Burke, \& D. Nelson (Eds). Advancing woman's cancers: research \& Practice P 15. Malden, M:A: Blackwell Publishers.

[5].Federal Ministry of Education (2004), National Policy on Education Lagos Government Press.

[6].Nwankwo, J.I. (1982). Educational Administration: Theory and Practice, New Delhi: Bisi Books with Vikas

Publishing House PVT. P.14. 
[7].Okebukola O. (1996). Management of Secondary Schools yesterday, today and tomorrow, paper presented at the Annual Conference of Nigerian Secondary Schools Principal Lagos.

[8].Olaleye F.O. (2001). Gender factor in Secondary School administration in Osun State, Nigeria Unpublished Ph.D Thesis Obafemi Awolowo University, Ile-Ife, Nigeria.

[9].Olaleye, F.O. (2006). Gender differences of Principals in the management of school personnel as perceived by teachers in Osun State. Nigeria. Ife Journal of Theory and Research in Education 9(2) 24-29.

[10]. Onifade, A. (2004). Management: Office business Education. (Revised Edition), Abeokuta: KAPPCO Nigeria Limited.

[11]. Peretomode, V.F. (1991). Educational administration applied concept and the practical perspective for students and practitioners. Lagos: Joja Educational Reach and Publishers Ltd. 